\title{
Optimal synthesis of trigeneration systems subject to environmental constraints.
}

\author{
Monica Carvalho ${ }^{*}$, Luis Maria Serra, Miguel Angel Lozano \\ Department of Mechanical Engineering
}

Group of Thermal Engineering and Energy Systems (GITSE),

Aragon Institute of Engineering Research (I3A), University of Zaragoza, CPS de Ingenieros

(Ed. Agustín de Betancourt), C/ María de Luna, s/n, 50018, Zaragoza, Spain.

email: carvalho@unizar.es, serra@unizar.es,mlozano@unizar.es

* Corresponding author, email address carvalho@unizar.es, telephone +34 976 761883, fax +34 976762616 


\section{ABSTRACT}

Environmental information obtained through Life Cycle Analysis techniques has been incorporated into a Mixed Integer Linear Programming (MILP). The solution of the model provides the optimal configuration and operation of an energy supply system to be installed, minimizing the environmental burden associated with production of equipment and consumption of resources. Starting from a superstructure of cogeneration system with additional components highly interconnected, the energy supply system was optimized considering specific demands of a hospital located in Zaragoza, Spain. The objective functions took into account the kilograms of $\mathrm{CO}_{2}$ released and Eco-indicator 99 Single Score. Also considered were price of energy resources, price and amortization possibilities of the equipment and options for selling surplus electricity to the electric grid. The effect of electricity generation conditions on the optimal configuration was examined by varying the source of electricity production in Spain and considering natural gas/electricity mixes from alternate countries. The ratio between local electricity emissions and natural gas emissions ( $\alpha$ factor) was found to have the highest impact on the configuration of the system. Therefore the $\alpha$ factor could be considered the strongest influencing factor when deciding the optimal configuration of a system that minimizes environmental loads.

Keywords: Trigeneration; Mixed Integer Linear Programming (MILP); Optimization; Ecoindicator 99; $\mathrm{CO}_{2}$ emissions; Life Cycle Assessment (LCA). 


\section{INTRODUCTION}

The need to consider environmental loads/impacts as an additional design factor in energy supply systems is ever increasing due to rising environmental conscience worldwide and stricter requirements to reduce the environmental impact of modern society. The Life Cycle Assessment is a tool that provides a global perspective of environmental loads and has the potential to fulfill this need for an adequate design tool [1].

Life Cycle Assessment (LCA) is an objective process that evaluates the environmental loads associated with a product, process, or activity, identifying and quantifying the use of mass and energy as well as the emissions to the environment. LCA also determines the impact of using such resources and emissions by evaluating and carrying out strategies of environmental improvement. Interestingly, LCA has been given other uses, such as identifying steps of industrial processes that need improvement and comparing systems, processes, services and alternative products [2]. LCA can therefore be considered an adequate environmental design tool for energy supply systems, as it is a suitable methodology to evaluate alternative technical proposals for the same issue and identify the most favorable alternative for the environment.

According to IPCC [3], increasing emissions of greenhouse gases (GHG) related to human activities since preindustrial times have led to marked increases in atmospheric concentrations of the long-lived GHG carbon dioxide $\left(\mathrm{CO}_{2}\right)$, methane $\left(\mathrm{CH}_{4}\right)$, nitrous oxide $\left(\mathrm{N}_{2} \mathrm{O}\right)$,

perfluorocarbons (PFCs), hydrofluorocarbons (HFCs), sulphur hexafluoride ( $\left.\mathrm{SF}_{6}\right)$, hydrochlorofluorocarbons (HCFCs), and other ozone-depleting substances at varying rates. Human activities that contribute to climate change include major burning of fossil fuels, 
occurring when coal, oil, or natural gas are burned to produce energy for transportation, manufacturing, heating, cooling, and electricity generation.

Since 1993, the Council Directive 93/76/EEC [4] (regarding the limitation of $\mathrm{CO}_{2}$ emissions through the improvement of energy efficiency in buildings) explicitly recognizes the important role of buildings for total $\mathrm{CO}_{2}$ emissions. However, gradual changes towards a service economy and new installations for thermal comfort have considerably increased energy consumption and emissions of buildings. According to Directive COM 2002/91/EC [5] on the energy performance of buildings, residential and tertiary sectors are responsible for more than $40 \%$ of final energy consumption in the European Community. This directive imposes that new buildings with a total usable space area over $1000 \mathrm{~m}^{2}$ take into account the technical, environmental, and economic feasibility of alternative energy systems, such as cogeneration, before construction starts. Following this, Directive COM 2004/8/EC [6] favored microcogeneration systems $(<50 \mathrm{kWe})$ and small-scale cogeneration $(<1000 \mathrm{kWe})$, promoting such cogeneration technologies in residential and tertiary sectors. In Spain, RD 616/2007 [7] (transposing of COM 2004/8/EC in Spanish legislation) created a stable framework for extensive promotion and public support of cogeneration.

Polygeneration systems have an important potential for reducing the consumption of energy and natural resources, but are undoubtedly underutilized [8]. Incorporating sustainable development into the design and planning process should consider, among others, the following concepts: i) increased efficiency of energy and materials; ii) reduction of unit cost of final products; and iii) reduction of environmental burden. 
The synthesis of energy systems implies searching for a design that minimizes or maximizes an objective function, such as cost, environmental load, and thermodynamic efficiency. The search process is bound by the system's model, which is expressed by equality and inequality mathematical restrictions. The design methodology must provide systems that produce energy services efficiently, are capable of adapting to different markets and demand conditions, and operate with minimal cost. The review by Chicco and Mancarella [9] summarizes the characteristics of optimization methods for polygeneration systems presented in recent publications, including time scale, objective function, and solution method. Integer programming methods satisfy the stated requirements and capture the complexity of polygeneration systems by i) considering a superstructure that contains all alternatives, ii) representing all possible options of configuration/operation through binary variables (0-1), and iii) expressing flows and funds (physic and economic) by continuous variables [10-14].

In this paper the synthesis of a trigeneration system to be installed in a hospital located in Zaragoza (Spain) has been accomplished from an environmental viewpoint, considering the kilograms of $\mathrm{CO}_{2}$ released in the atmosphere and the Eco-indicator 99 (EI-99) Single Score. The latter was included to broaden environmental considerations in the impact assessment. The objective function was then changed to optimize the annual total cost (€/y) and verify the changes implied. Innovations of this study include a unique analysis of the impact of environmental criteria on the optimal synthesis of trigeneration systems and the proposal of a design parameter that provides information on the optimal structure. 


\section{TRIGENERATION SYSTEM AND ECONOMIC EVALUATION}

This study analyzed the energy demands of a medium-sized hospital with 500 beds, located in Zaragoza (Spain). The energy demands considered were heat (domestic hot water and heating), cooling, and electricity.

The synthesis of a trigeneration system's configuration begins with the creation of a superstructure which must include all feasible process options and connections, based on appropriate process integration [15]. Heat integration methodologies are particularly powerful tools that should be included in the synthesis of trigeneration systems. In this respect, a broader perspective on the consideration of heat integration in the configuration of the superstructure of a polygeneration system is presented in [8]. Furthermore, Ryan [16] presents considerations on heat recovery, selection of the best absorption chiller type and configurations for optimal integration. Simulation of the main components of a trigeneration system and a fast and interactive way to design optimal heat integrated schemes using commercial equipment data is presented in [17].

The superstructure must include all features that are potentially part of an optimal solution, even if presented in a redundant manner. After the optimization process, the superstructure is reduced to an optimal configuration. In this study, selection of equipment took into account input/output utility flows based on appropriate energy process integration. The superstructure shown in Figure 1 is proposed considering heat and power sources (gas turbine, gas engine, steam boiler, hot water boiler, to name a few). Also considered were the requirements temperature, heat, power, and cooling - of i) the energy services demanded by the consumer 
center; ii) different pieces of equipment. Technical production coefficients of equipment were evaluated prior to the inclusion in the superstructure.

Figure 1

The superstructure of a trigeneration system that satisfies energetic demands of heat (domestic hot water and heating), cooling, and electricity should account for the possibility of installing energy production technologies such as TGVA (gas turbine + recuperation boiler, producing steam and hot water), CGVA (steam boiler), MGWH (gas engine + hot water heat recovery system), ICVA (steam-hot water heat exchanger), CGWH (hot water boiler), ICWH (hot water-cooling water heat exchanger), FAVA (double effect absorption chiller, driven by steam), FAWH (single effect absorption chiller, driven by hot water), FMWR (mechanical chiller, driven by electricity and cooled by water), and ICWR (cooling tower, to evacuate the heat from the cooling water). The functional unit (reference to all inputs and outputs of the system) was the production of energy services during one year (y) of operation (8760 hours) of the trigeneration plant.

The available utilities were CG (natural gas), VA (high temperature steam, $180^{\circ} \mathrm{C}$ ), WH (hot water, $90^{\circ} \mathrm{C}$ ), WR (cooling water, $\mathrm{t}_{0}+5^{\circ} \mathrm{C}$ ), AA (ambient air, $\mathrm{t}_{0}$ ), WC (cold water, $5^{\circ} \mathrm{C}$ ), and EE (electricity)

\subsection{Energy demand}

The study extended over a period of one year, distributed in 24 representative days (one working day and one holiday/weekend day for each month), each day being divided into 24 
hourly periods. Representative energy demand patterns for each representative day were calculated according to the procedure described by Sanchez [18], which estimated monthly, daily, and hourly profiles of the different energy demands based on the size of the hospital and its geographical location in Spain. Annual electricity consumption of the hospital was $3250 \mathrm{MWh} / \mathrm{y}$, cooling demand was $1265 \mathrm{MWh} / \mathrm{y}$, and heat requirements (domestic hot water and heating) were $8059 \mathrm{MWh} / \mathrm{y}$.

\subsection{Equipment}

Table 1 depicts the selected equipment and technical production coefficients for the superstructure. The rows contain potential technologies for installation and the columns contain the utilities. The production coefficient with a highlighted $\mathbf{1}$ shows the flow that defines the equipment's capacity. Positive coefficients indicate that the utility is produced, while negative coefficients indicate the consumption of such utility.

\section{Table 1}

Taking MGWH technology in Table 1 as an example, electricity is the main product as its coefficient is 1 . To produce $1 \mathrm{MW}$ of electricity (EE), $2.45 \mathrm{MW}$ of natural gas (CG) will be consumed, recuperating $0.96 \mathrm{MW}$ of hot water (WH), and evacuating $0.20 \mathrm{MW}$ of heat to cooling water (WR). Consequently, the electrical efficiency of MGWH is $1 / 2.45(\sim 41 \%)$. All technology and equipment considered in the optimization were commercially available; therefore the size/configuration of the system was determined in terms of pieces of equipment. The data shown in Table 1 was obtained from equipment catalogs and consultations with manufacturers. $\mathrm{CI}_{\mathrm{i}}$ was the investment cost of the equipment of technology 
i, obtained from catalog prices and multiplied by a simple module factor that took into account aspects such as transportation and installation. According to current conditions in Spain, an amortization and maintenance factor fam $=0.23 \mathrm{y}^{-1}$ was considered.

\subsection{Gas and electricity rates}

In the case of natural gas in Spain, the consumer chooses the most adequate rate for the consumption volume and supply pressure. This investigation considered a constant purchase cost of $C_{g}=0.025 € / \mathrm{kWh}$ for natural gas [19], which includes taxes and the distribution of fixed costs throughout the estimated annual consumption.

Electricity rates are composed of two terms, a power term (dependent on the contracted capacity) and an energy term (dependent on energy consumption). Considering other costs such as taxes, and approximating the distribution of fixed costs, an electricity purchase price of $0.095 € / \mathrm{kWh}[20]$ was utilized throughout the studied year. However, there is a supplement that discriminates the price of electricity by hour of use. The day was divided into two periods: 4 on-peak hours with a $37 \%$ increase in price, and the 20 remaining hours with no increase or discount in price [20]. Final electricity price, $C_{e p}$, was $0.095 € / k W h$ for off-peak hours, and $0.130 € / \mathrm{kWh}$ for on-peak hours.

For the sale of surplus autogenerated electricity, the tariff and premium depend on the power output and fuel utilized by the plant. Considering the energy demand of the hospital and the nominal power of the cogeneration modules (cogeneration installations using natural gas, $1000-10,000 \mathrm{~kW}$ capacity), $\mathrm{C}_{\mathrm{es}}=0.077 € / \mathrm{kWh}$ was obtained as the price for sold electricity [21]. Spanish legislation establishes the Equivalent Electrical Efficiency (EEE, calculated on 
an annual basis), which compares the efficiencies of cogeneration systems with electricityonly generation systems:

$$
\mathrm{EEE}=100 \mathrm{~W}_{\mathrm{c}} /\left(\mathrm{F}_{\mathrm{c}}-\mathrm{Q}_{\mathrm{cc}} / 0.9\right)
$$

where $\mathrm{W}_{\mathrm{c}}$ is the cogenerated work, $\mathrm{F}_{\mathrm{c}}$ the consumption of natural gas by the cogeneration module, and $\mathrm{Q}_{\mathrm{cc}}$ is the cogenerated useful heat. Spanish legislation demands that cogeneration systems must have an EEE equal or higher than the electrical efficiency of the reference central power plant using the same type of energy source in order to be licensed. For natural gas, minimum EEE is $59 \%$ for turbines and $55 \%$ for engines [21]. Although EEE can be considered a pillar of high efficiency cogeneration assessment, it was not included among the methodologies for determining the efficiency of the cogeneration process in Directive COM 2004/8/EC [6]. The EEE eligibility criterion was considered because it takes into account Spanish legislation - although this same reason is a source of controversy for authors around the conclusions the use of EEE leads to [22].

\section{ENVIRONMENTAL EVALUATION}

Environmental optimization was carried out based on two criteria: i) $\mathrm{CO}_{2}$ emissions and ii) Eco-indicator 99 (EI-99). Global warming and its associated climate change are one of the main medium- and long- term identified threats of GHG with great consequences on the global scale. $\mathrm{CO}_{2}$ emissions were chosen for optimization in this study because they accounted for $77 \%$ of total global anthropogenic GHG emissions in 2004 [23]. EI-99 is a global environmental indicator that encompasses several impact categories and was included to broaden the environmental perspective. 
Both criteria, $\mathrm{CO}_{2}$ emissions and EI-99, were evaluated by applying the LCA technique. An LCA study consists normally of four stages [1]: Goal and Scope definition, Life Cycle Inventory (LCI), Life Cycle Impact Assessment (LCIA), and Interpretation. Databases were utilized in the LCI to obtain $\mathrm{CO}_{2}$ emission values. The EI-99 method was utilized for the LCIA, where the values of eleven impact categories were added into three damage categories, weighted and aggregated into an index. This index is the Single Score, which represents the overall environmental load and where one point can be interpreted as one thousandth of the annual environmental load of one average European inhabitant.

Changes in lifestyle and behavior can contribute to climate change mitigation across all sectors. Similarly, management practices can also have a positive role through the use of technologies that result in considerable reduction of environmental impacts related to energy use in buildings, for example. Substantial reductions in $\mathrm{CO}_{2}$ emissions from energy use in buildings can be achieved using energy-efficient technologies that already exist, with significant savings in primary energy being possible. Design strategies for energy-efficient buildings should include a selection of systems that make the best use of energy sources and also operate optimally. Additionally, $\mathrm{CO}_{2}$ emissions from electricity use in buildings can also be altered on the supply side since electricity can be derived from fuels with lower carbon content than currently available fuels. Because climate change mitigation in the buildings' sector includes numerous measures aimed at electricity saving, it is useful to associate mitigation potentials to carbon dioxide emissions.

The extent of the impact of climate change strategies is connected to the choices of primary energy for consumption and the efficiency of technologies used for heating and cooling needs. 
The Mitigation of Climate Change report by IPCC [24] refers to co- and tri- generation systems as effective GHG mitigation options in buildings.

In EI-99, adverse effects on the environment are divided into three broad damage categories: Human Health, Ecosystem Quality (flora and fauna), and Resources of the Earth.

Human Health includes the idea that all human beings, in present and future, should be free from environmentally transmitted illnesses, disabilities and premature deaths. Ecosystem Quality includes the idea that non-human species should not suffer from disruptive changes to their populations and geographical distribution. Lastly, Resources includes the idea that the nature's supply of non-living goods, which are essential to human society, should also be available for future generations [25].

Under the damage category of Human Health, EI-99 accounts for the number of people as well as the length of illnesses and life years lost due to premature death from environmental effects. This method is used by the World Health Organization and the World Bank [26]. Impacts on human health are well expressed by the Disability Adjusted Life Years (DALY). DALY is a health-gap measure that extends the concept of potential years of life lost due to premature death to include equivalent years of 'healthy' life lost by virtue of being in state of poor health or disability [27]. One DALY, therefore, is equal to one year of healthy life lost. Human Health accounts for effects caused by ozone layer depletion, effects caused by ionizing radiation, damage caused by climate change, respiratory effects caused by organic and inorganic substances, and carcinogenic effects on humans. 
Ecosystem Quality quantifies environmental impacts on species' diversity, including vascular plants and lower organisms, considering reversible or irreversible disappearance or stress on a species in a certain region during a certain time-frame. This damage category accounts for the consequences of land use, damage caused by combined effects of acidification and eutrophication, and damage caused by ecotoxic effects. There is no uniform parameter for this purpose, such as the DALY [25]. Toxicity is measured by the Potentially Affected Fraction of species $\left(\mathrm{PAF}\right.$, in $\left.\mathrm{PAF} \cdot \mathrm{m}^{2} \cdot \mathrm{y}\right)$, which quantifies the toxic effect on organisms (mostly lower forms) that live in water and soil (toxic stress). Damages resulting from acidification, eutrophication and land-use are measured as the percentage of species that have disappeared in a certain area due to the environmental load (Potentially Disappeared Fraction, PDF, in $\left.\mathrm{PDF} \cdot \mathrm{m}^{2} \cdot \mathrm{y}\right)$. As PAF and PDF are very different measures, the damage cannot be simply added. Considering the level at which species (assuming all species have equal importance) become affected and at which level they disappear, a conversion factor has been developed in which the PAF results are divided by 10 before they can be added to the PDF [25].

With respect to the damage category of Resources, the models in EI-99 only consider the effects caused by extraction of minerals and fossil fuels. These effects are evaluated as the additional energy needed in the future to extract lower grade mineral and fossil resources. The additional energy is called surplus energy and is measured in MJ surplus. For minerals, lower grade ores are considered to require more effort to process and larger amounts of electrical or fossil fuel energy per unit of metal produced [26]. For fossil fuels, surplus energy is based on future use of nonconventional resources, especially oil shale and tar sands. The point in the future has been chosen as the time at which five times the cumulative extraction of the resource before 1990 has been extracted [25]. 
EI-99 presents three different approaches to obtain the EI-99 Single Score (combining the contribution of each damage category): Egalitarian, Hierarchist, and Individualist. The Hierarchist version $(\mathrm{H} / \mathrm{H})$ was selected for the damage model herein because of its balanced time perspective, as a consensus among scientists determined inclusion of environmental effects [25] and strong-held belief in preventing environmental problems through regulation [28]. In the Hierarchist version $(\mathrm{H} / \mathrm{H})$, Human Health and Resources each contribute $30 \%$, while Ecosystem Quality contributes $40 \%$ to the final value of EI-99 Single Score [25].

Figure 2 shows the relative contribution of the eleven impact subcategories considered in the three damage categories to the overall result of the Single Score (Hierarchist approach, H/H) within Europe. Respiratory Effects, Climate Change and Carcinogenic Effects dominate Human Health damages. Land-use dominates Ecosystem Quality, and Resources is dominated by fossil fuels.

Figure 2

SimaPro [29] was the specialized LCA tool used to calculate the $\mathrm{CO}_{2}$ emissions and EI-99 Single Score associated with each piece of equipment included in the superstructure and with the natural gas and electricity consumed in the energy production system. SimaPro includes several inventory databases containing thousands of processes, in addition to the most important impact assessment methods.

\section{1 $\mathrm{CO}_{2}$ emissions calculation}


Natural gas was characterized utilizing the related emissions of combustion of natural gas (Energy gas I) from the IDEMAT database [30] and the total aggregated system inventory for a natural gas user in Spain (Natural Gas, high pressure, at consumer/ES E) from the Ecoinvent database [31]. Natural Gas, high pressure, at consumer/ES E considers gas field exploration, natural gas distribution, natural gas production, long distance transport, regional distribution, and local supply. The $\mathrm{CO}_{2}$ emissions associated with the consumption of natural gas in Spain were obtained by utilizing SimaPro, calculated as $\mathrm{EM}_{\mathrm{g}}=0.272 \mathrm{~kg} \mathrm{CO}$ per $\mathrm{kWh}$ of consumed natural gas.

The $\mathrm{CO}_{2}$ emissions associated with the local electricity (Spanish electricity mix) were also calculated by SimaPro, utilizing the Ecoinvent database and considering the following proportions: 25.8\% Coal, 24.4\% Natural Gas -combined cycle-, 19.7\% Nuclear, 10.4\% Others (biomass, Natural Gas -cogeneration-, minihydraulic), 9.4\% Eolic, 9.4\% Hydraulic and $0.9 \%$ Fuel-gas [32]. The average $\mathrm{CO}_{2}$ emissions associated with electricity in Spain in 2007 was $\mathrm{EM}_{\mathrm{e}}=0.385 \mathrm{~kg} \mathrm{CO} 2$ per $\mathrm{kWh}$ consumed.

\subsection{EI-99 Single Score calculation}

In order to calculate the EI-99 score, the following steps are necessary:

1. Evaluation of the inventory of resource extraction, land-use and all relevant emissions in all processes that form the life cycle of the equipment or utility. The combustion of $1 \mathrm{kWh}$ of natural gas (Energy gas I, from the IDEMAT database) was chosen to illustrate the calculation of the EI-99 Single Score. The inventory is shown in Table 2. 
2. Consultation of the characterization factors (Table 3) to evaluate the contribution of each substance of the inventory towards the different impact categories (Table 4).

Table 3

Values in Table 4 were obtained by multiplying each substance of the inventory (Table 2) by its corresponding characterization factor (Table 3). Substances can contribute to more than one impact category. For example, nitrogen oxides contribute to respiratory effects and acidification/eutrophication impact categories. The different impact categories are combined into the three damage categories (Human Health, Ecosystem Quality, and Resources).

Table 4

3. Multiplication of the damage category values (A in Table 4) by their corresponding normalization factors ( $B$ in Table 5) in order to build the damage model. This multiplication yields the dimensionless value $\mathbf{C}$, which represents the normalized environmental load corresponding to each damage category.

Table 5

4. Application of a set of weighting factors ( $\boldsymbol{D}$ values in Table 6) to the $\boldsymbol{C}$ values of the damage categories in order to obtain the EI-99 Single Score,. 
Further EI-99 calculations are not presented herein due to space limitations. The same procedure was applied to the total aggregated system inventory for both natural gas and electricity mix users in Spain. The Single Score obtained was $\mathrm{SS}_{\mathrm{g}}=0.0378$ points per $\mathrm{kWh}$ consumed for natural gas and $\mathrm{SS}_{\mathrm{e}}=0.0226$ points per $\mathrm{kWh}$ consumed for the Spanish electricity mix.

Table 7 shows the EI-99 Single Score (total and contribution of each damage category) and $\mathrm{CO}_{2}$ emissions for $1 \mathrm{kWh}$ of consumed natural gas.

\section{Table 7}

According to Table 7, the Resources category was most frequently the category with highest contribution to the total EI-99 Single Scores. For example, combustion of natural gas contributed $47 \%$ ( 0.0178 points per $\mathrm{kWh}$ of consumed natural gas) to the EI-99 Single Score of natural gas. In general, the aspects considered in the aggregated inventory for a natural gas user in Spain have a considerable contribution to the EI-99 Single Score. An important share of the environmental burden is related to the production and processing of natural gas [33]. With respect to $\mathrm{CO}_{2}$ emissions, the highest contribution (almost $89 \%$ ) corresponded to natural gas combustion.

Table 8 shows the EI-99 Single Scores and $\mathrm{CO}_{2}$ emissions for the different contributors to the electricity mix in Spain. The final value for the electricity mix in Spain is obtained by multiplying each contributor by its corresponding proportion. Values in Table 8 were 
obtained from the Ecoinvent database, which provides environmental loads associated with the production of electricity at each specific power plant.

Table 8

When analyzing the electricity mix breakdown in Spain, it becomes apparent that the utilization of natural gas is penalized in combined cycle and in cogeneration (i.e. high EI-99 points for Resources). Natural gas is a more environmentally sound fuel than coal when considering only $\mathrm{CO}_{2}$ emissions. However, when applying the EI-99 method, the difference in characterization factors between natural gas and coal (4.55 MJ surplus/kg for natural gas and $0.252 \mathrm{MJ}$ surplus/kg for coal [29]) balances out the impact category of fossil fuels, resulting in similar final Single Scores for both. Coal contributes towards $25.8 \%$ of the electricity mix and is responsible for $46 \%$ of the final value of the EI-99 Single Score. In a similar fashion, natural gas in a combined cycle contributes towards $24.4 \%$ of the electricity mix and is responsible for $41 \%$ of the final environmental load (EI-99 Single Score).

\subsection{Equipment}

The $\mathrm{CO}_{2}$ emissions and EI-99 Single Score associated with the production of each type of technology were calculated utilizing SimaPro following the same procedure explained in the previous sections.

Data on the material composition and manufacturing of the equipment were obtained from consultation with the manufacturers and incorporated into SimaPro through IDEMAT, 
Ecoinvent, and ETH-ESU [34] databases. The databases accounted for natural resources, emissions, and impact of every material entered, beginning at the extraction from the ore/mine/well and including the transformations necessary to produce the material and assemble the equipment. Average product manufacturing was considered for each material (Ecoinvent) and transportation of the equipment (average of $300 \mathrm{~km}$ ) fulfilled European directive EURO V [35]. The following assumptions were also made: i) $100 \%$ of materials was landfilled (worst case scenario, with no recycling), ii) any oil or fluid was considered as an emission into the soil, and iii) gases (R134a, for example) were considered to be discharged into the atmosphere.

Table 9 presents the technologies and their associated main material composition, $\mathrm{CO}_{2}$ emissions, $\mathrm{CO}_{2} \mathrm{I}$, and the Single Score obtained by applying EI-99, SSI.

Table 9 


\section{OPTIMIZATION MODEL}

The issue to be solved consists of selecting the optimal combination of technologies, specifically the type of technology and installed power that meets the energy demands set by the consumer center and establishes the operational mode for the installed technologies for each defined time period of the year.

An optimization model was built based on mixed integer linear programming and its solution provides the means for selecting the most convenient configuration and operation modes. The model represented the superstructure, considering all possible configuration and operation options as well as particular circumstances (such as demand and tariffs).

The first environmental objective function considered was to minimize the total annual carbon dioxide emissions $\left(\mathrm{CO}_{2 \text { tot }}\right)$, which included the annual fixed emissions of the equipment $\left(\mathrm{CO}_{2 \mathrm{fix}}\right)$ and the annual operation emissions $\left(\mathrm{CO}_{2 \mathrm{ope}}\right)$ associated with operation of the system.

$$
\text { Min } \mathrm{CO}_{2 \text { tot }}=\mathrm{CO}_{2 \text { fix }}+\mathrm{CO}_{2 \text { ope }}
$$

The annual fixed impact of the equipment $\left(\mathrm{CO}_{2 \mathrm{fix}}\right)$ was expressed by

$$
\mathrm{CO}_{2 \text { fix }}=\mathrm{fam}_{\mathrm{e}} \cdot \Sigma_{\mathrm{i}} \mathrm{NIN}(\mathrm{i}) \cdot \mathrm{CO}_{2} \mathrm{I}(\mathrm{i})
$$

where NIN(i) and $\mathrm{CO}_{2} \mathrm{I}$ (i) were, respectively, the number of pieces of equipment installed and the environmental impact required to produce each piece of equipment for technology $i$. The environmental amortization factor $\left(\mathrm{fam}_{\mathrm{e}}\right)$ represents the share of global environmental impact throughout the system's lifetime and was considered equal to $0.10 \mathrm{y}^{-1}$. 
Considering that the year was divided into $d$ representative days, which were in turn subdivided into $h$ hours, $(\mathrm{d}, \mathrm{h})$ represented the $h$ th hour of the $d$ th representative day. The annual operation impact $\left(\mathrm{CO}_{2 o p e}\right)$ associated with the operation of the system was expressed by

$$
\mathrm{CO}_{2 \text { ope }}=\Sigma_{\mathrm{d}} \Sigma_{\mathrm{h}}\left[\mathrm{EM}_{\mathrm{g}} \cdot \mathrm{F}_{\mathrm{g}}(\mathrm{d}, \mathrm{h})+\mathrm{EM}_{\mathrm{e}} \cdot \mathrm{E}_{\mathrm{p}}(\mathrm{d}, \mathrm{h})-\mathrm{EM}_{\mathrm{e}} \cdot \mathrm{E}_{\mathrm{s}}(\mathrm{d}, \mathrm{h})\right]
$$

$F_{g}$ was the consumption of natural gas, and $E_{p}$ and $E_{s}$ were the amount of electricity purchased and sold, respectively. $\mathrm{EM}_{\mathrm{e}} \cdot \mathrm{E}_{\mathrm{s}}(\mathrm{d}, \mathrm{h})$ was considered as the impact avoided elsewhere with the sale of electricity produced by the cogeneration module.

The second environmental objective function was to minimize the EI-99 Single Score, which evaluated global environmental impact (considering human health, ecosystem quality, and consumption of resources). This score considered the total annual impact $\left(\mathrm{SS}_{\mathrm{tot}}\right)$, including the annual fixed impact of the equipment $\left(\mathrm{SS}_{\mathrm{fix}}\right)$ and the annual operation impact $\left(\mathrm{SS}_{\mathrm{ope}}\right)$ associated with the operation of the system. Equations (2) - (4) were changed to

$$
\begin{aligned}
& \text { Min } \mathrm{SS}_{\text {tot }}=\mathrm{SS}_{\text {fix }}+\mathrm{SS}_{\text {ope }} \\
& \mathrm{SS}_{\text {fix }}=\mathrm{fam}_{\mathrm{e}} \cdot \Sigma_{\mathrm{i}} \mathrm{NIN}(\mathrm{i}) \cdot \mathrm{SSI}(\mathrm{i}) \\
& \mathrm{SS}_{\text {ope }}=\Sigma_{\mathrm{d}} \Sigma_{\mathrm{h}}\left[\mathrm{SS}_{\mathrm{g}} \cdot \mathrm{F}_{\mathrm{g}}(\mathrm{d}, \mathrm{h})+\mathrm{SS}_{\mathrm{e}} \cdot \mathrm{E}_{\mathrm{p}}(\mathrm{d}, \mathrm{h})-\mathrm{SS}_{\mathrm{e}} \cdot \mathrm{E}_{\mathrm{s}}(\mathrm{d}, \mathrm{h})\right]
\end{aligned}
$$

A third objective function was introduced into the model to consider the economic aspect of the energy supply system installed in terms of the total annual cost $C_{\text {tot }}$ (in $€ / y$ ), which minimized equipment and fuel costs as well as purchase/sale of energy services. Equations (2) - (4) were changed to: 


$$
\begin{aligned}
& \text { Min } \mathrm{C}_{\text {tot }}=\mathrm{C}_{\text {fix }}+\mathrm{C}_{\mathrm{ope}} \\
& \mathrm{C}_{\text {fix }}=\mathrm{fam} \cdot \Sigma_{\mathrm{i}} \mathrm{NIN}(\mathrm{i}) \cdot \mathrm{CI}(\mathrm{i}) \\
& \mathrm{C}_{\mathrm{ope}}=\Sigma_{\mathrm{d}} \Sigma_{\mathrm{h}}\left[\mathrm{C}_{\mathrm{g}} \cdot \mathrm{F}_{\mathrm{g}}(\mathrm{d}, \mathrm{h})+\mathrm{C}_{\mathrm{ep}}(\mathrm{d}, \mathrm{h}) \cdot \mathrm{E}_{\mathrm{p}}(\mathrm{d}, \mathrm{h})-\mathrm{C}_{\mathrm{es}} \cdot \mathrm{E}_{\mathrm{s}}(\mathrm{d}, \mathrm{h})\right]
\end{aligned}
$$

Operation was subject to capacity limits, production restrictions, and balance equations, which were presented in Lozano et al. [13]. The investigation led to a complete economic study considering legal constraints imposed to feed the surplus autogenerated electricity into the grid at a regulated feed-in tariff. The effects of the financial market conditions and energy prices in the optimal structure of the system were also considered.

\section{RESULTS AND DISCUSSION}

Once the scenario was completely defined by the optimization model and conditions previously specified (energy demands, economic and environmental evaluations), the following results were obtained. The model was solved by LINGO [36] by freely selecting the technologies to be installed and minimizing the different objective functions considered. Table 10 shows the results for the optimization of annual $\mathrm{CO}_{2}$ emissions, EI-99 Single Score, and the total annual cost.

Table 10

The configuration obtained for the optimal $\mathrm{CO}_{2}$ and EI-99 Single Score is the same and both suggest the installation of "conventional" equipment, including hot water boilers, mechanical chillers, and cooling towers. 
Economic optimization suggested the installation of cogeneration modules, hot water-cooling water heat exchangers, and one absorption chiller. The system took advantage of the lower purchase cost of natural gas and achieved profit by selling the cogenerated electricity to the electric grid.

The study by Carvalho et al. [37] obtained and analyzed the thermal loads of a tertiary sector building while considering different geographic locations to represent the climatic variation in Spain. Thermal loads experienced important variation with climatic conditions, resulting in different power to heat ratios for buildings. Influences of local economic/environmental conditions on the optimal configuration of the energy supply system were also studied in [37]. However, even with such different heat/cooling demands, the installation of cogeneration modules only reduced emissions in the Canary Islands, which have a different electricity mix mostly based on fuel-gas. The optimal environmental results suggested the installation of conventional equipment and purchase of electricity from the Spanish electric grid for peninsular locations. The economic optimal results suggested the installation of trigeneration for all locations except those with no cooling demand.

Cogeneration and trigeneration systems present higher efficiency than conventional energy supply systems. However, this does not necessarily represent reduction in emissions, which depends on the local energy supply [38-47].

Given the energy demands, production coefficient for technologies, system lifetime and environmental loads associated with construction of equipment, the parameters that could significantly influence the optimal system structure and operation are the environmental loads 
associated with the consumption of natural gas and of electricity. Therefore, the following subsections represent two sensitivity analyses to study the influence of different energy supply combinations on the optimal configuration of an energy supply system. For this purpose, the $\alpha$ factor was developed and defined as the ratio between local electricity emissions and natural gas emissions. In this ratio, Local electricity emissions was defined as the total $\mathrm{CO}_{2}$ emissions resulting from generation of electricity in the power plants that supply the grid (which could be single or mixed fuel sources); while Natural gas emissions was defined as the $\mathrm{CO}_{2}$ emissions related to combustion of natural gas plus the total aggregated system inventory for a natural gas user (details in subsection 3.1).

\subsection{Effect of the variation of the source of electricity in Spain}

For this analysis, $100 \%$ of electricity was considered to originate from a single-fuel representative power plant (data from Table 8). Table 11 shows the $\alpha$ factors, the configuration of the system, and main flow values as a function of the origin of electricity.

Table 11

It was previously noted (Table 10) that cogeneration was not installed when Spanish natural gas and electricity mix $(\alpha=1.42)$ were considered. However, Table 11 shows that for natural gas combined cycle systems, cogeneration was installed $(\alpha=1.46)$. Trigeneration (cogeneration with absorption chillers) was installed for fuel-gas $(\alpha=2.38)$ as well as for coal systems ( $\alpha=3.75$ ). The results obtained confirm that the emission savings by cogeneration and trigeneration depend highly on the source of electricity substituted. 
The primary factors that alter $\mathrm{CO}_{2}$ emissions from electricity generation are the growth in demand for electricity, the type of fuels or energy sources used for generation, and the thermal efficiencies of the power plants. A number of contributing factors influencing these primary factors can also be identified: economic growth, price of electricity, amount of imported electricity, weather, fuel prices, and amount of available generation from hydroelectric, renewable, and nuclear plants. The contribution of weather can be seen, for example, in the contribution of hydraulic electricity to the total available electricity, where the amount of available hydroelectric power is strongly affected by precipitation patterns.

From 1996 to 2007, the values of the $\mathrm{CO}_{2}$ emissions associated with the production of electricity in Spain have oscillated between 0.350 and $0.450 \mathrm{~kg} \mathrm{CO} / \mathrm{kWh}$ [49]. The $\mathrm{CO}_{2}$ emissions associated with the Spanish electricity mix considered in this paper $\left(\mathrm{EM}_{\mathrm{e}}=0.385 \mathrm{~kg}\right.$ $\mathrm{CO}_{2} / \mathrm{kWh}$ ) have the particular feature of being the limit value at which cogeneration modules are not installed. When changing the value of $\alpha$ to $1.43\left(\mathrm{EM}_{\mathrm{e}}=0.390 \mathrm{~kg} \mathrm{CO} / \mathrm{kWh}\right)$, the solution of the model yields an optimal configuration that presents cogeneration modules.

Options to limit the emission of $\mathrm{CO}_{2}$ from electricity generation are to encourage reduction of the overall consumption of electricity through energy efficiency and conservation initiatives, and/or to replace fossil-fueled generation with nonfossil-fueled alternatives, such as nuclear, hydroelectric, and other renewable energy sources.

From the beginning of 2003 until the end of 2008, the electrical power installed in peninsular Spain increased by 31,058 MW (from 59,820 MW to 90,878 MW). Natural gas combinedcycle systems contributed with an increase of 18,359 MW (from $3136 \mathrm{MW}$ to 21,675 MW), which represents $60 \%$ of the total increase. Between 2002 and 2008, the net electricity 
generation of the Spanish peninsular electricity system increased by $65,157 \mathrm{GWh} / \mathrm{y}$ (from $213,144 \mathrm{GWh} / \mathrm{y}$ to $278,301 \mathrm{GWh} / \mathrm{y})$. The increment in the production of natural gas combined-cycle systems between 2002 and 2008 was 85,978 GWh/y (from $5308 \mathrm{GWh} / \mathrm{y}$ to 91,286 GWh/y), which not only allowed coverage of the increase in net electricity generation but also displaced part of the electricity production from coal and/or fuel-gas. If such a displacement is maintained (which is the current trend in Spain [49]), it can be deduced that combined cycle is a good reference for an environmental analysis of cogeneration and other alternative electricity sources.

\subsection{Effect of the variation of the electricity and natural gas supply}

This subsection analyzes the effects of using different values for the emissions of $\mathrm{CO}_{2}$ associated with electricity and natural gas on the configuration and operation of systems. For this, it was assumed that the hospital located in Zaragoza could be supplied with electricity and natural gas originating from alternate countries. Table 12 shows the countries, emission values, and associated $\alpha$ factors indicating the ratio between local electricity $\mathrm{CO}_{2}$ emissions and natural gas $\mathrm{CO}_{2}$ emissions. Table 13 shows the optimal configurations of the systems and main flows.

Table 12

Table 13

It was observed that there was a starting point between the range of $1.42-1.53$ (Spain and Japan) at which cogeneration was installed, and between the range of $1.53-2.61$ (Japan and 
United Kingdom), where installation of trigeneration started. Therefore, cogeneration was installed when the $\alpha$ factor was higher than 1.43 and from 2.00 onwards, absorption chillers were also installed. 


\section{CONCLUSIONS AND FINAL REMARKS}

The optimal configuration of trigeneration systems was obtained by considering the following environmental criteria: kilograms of carbon dioxide $\left(\mathrm{CO}_{2}\right)$ released and Eco-indicator 99 method (EI-99). The latter was included in order to consider more environmental aspects in the impact assessment.

Optimal configurations based on conventional equipment (such as hot water boilers, steam compression chillers and cooling towers) were obtained by separately minimizing $\mathrm{CO}_{2}$ emissions and then EI-99 Single Score for current conditions in Spain. Surprisingly, both optimal solutions maintained similar configurations in which the energy demands of the consumer center were satisfied utilizing conventional equipment. This demonstrates that emissions savings by cogeneration are highly dependent on the ratio between local electricity emissions and natural gas emissions.

Interestingly, switching to an economic objective required the installation of cogeneration modules and an absorption chiller, which are non-conventional equipment. The optimal solution revealed the possibility for sale of electricity to the electric grid as a means to profit, therefore achieving minimal annual final cost.

A sensitivity analysis was performed in order to examine the most influential factors on the structure and the operation of the system. This analysis kept all other values constant and maintained the objective function as the minimization of $\mathrm{CO}_{2}$ emissions. Thus, the ratio between local electricity emissions and natural gas emissions was initially modified by varying the origin of electricity in Spain. The results verified that cogeneration modules were 
installed when the energy supply was highly dependent on fossil fuels. A second analysis considered that the system could be supplied by energy supply mixes from different countries (varying only natural gas and electricity mix values). Based on this, the $\alpha$ factor (ratio between local electricity emissions and natural gas emissions) was found to have the highest impact on the configuration of a system that minimizes environmental loads.

The substantial impact of the $\alpha$ factor demonstrates that more energy-efficient technologies are not always the most appropriate from an environmental viewpoint. Reductions in environmental loads also depend on factors other than just the obvious energy consumption. This highlights the need for a more global perspective when considering the optimal configuration and operation of an energy supply system, which was demonstrated herein through the integration of environmental information into a MILP model.

\section{ACKNOWLEDGMENTS}

This work was developed within the framework of research project ENE2007-67122, funded in part by the Spanish Government (Energy program) and the European Union (FEDER program). Monica Carvalho is supported by the EU Program of High Level Scholarships for Latin America (A1ßan Scholarship No. E06D100314BR). 


\section{NOMENCLATURE}

AA

$\mathrm{C}_{\mathrm{es}}$

$\mathrm{C}_{\mathrm{ep}}$

$\mathrm{C}_{\mathrm{g}}$

$\mathrm{C}_{\text {fix }}$

$\mathrm{C}_{\text {ope }}$

$\mathrm{C}_{\text {tot }}$

CG

CGVA

CGWH

$\mathrm{CH}_{4}$

CI(i)

$\mathrm{CO}_{2}$

$\mathrm{CO}_{2} \mathrm{I}(\mathrm{i})$

$\mathrm{CO}_{\text {tot }}$

$\mathrm{CO}_{\text {2fix }}$

$\mathrm{CO}_{\text {2ope }}$

$\mathrm{D}$

DALY

$E_{d}$

$\mathrm{E}_{\mathrm{p}}$

$\mathrm{E}_{\mathrm{s}}$

EE

EEE

EI-99

$\mathrm{EM}_{\mathrm{e}}$

$\mathrm{EM}_{\mathrm{g}}$

$\mathrm{F}_{\mathrm{c}}$

$\mathrm{F}_{\mathrm{g}}$

fam

fame $_{e}$

FAVA
Ambient air

Market price of the electricity sold to the grid [ $€ / \mathrm{kWh}]$

Market price of the electricity purchased from the grid [€/kWh]

Market price of natural gas [€/kWh]

Annual cost of the equipment $[€ / y]$

Annual operation costs [€/y]

Total annual cost $[€ / y]$

Natural gas

Steam boiler

Hot water boiler

Methane

Investment cost of the equipment of technology i $[€]$

Carbon dioxide

$\mathrm{CO}_{2}$ emissions of the production of each piece of technology i $\left[\mathrm{kg} \mathrm{CO}_{2}\right]$

Total annual $\mathrm{CO}_{2}$ emissions $\left[\mathrm{kg} \mathrm{CO}_{2} / \mathrm{y}\right]$

Annual fixed $\mathrm{CO}_{2}$ emissions of the equipment $\left[\mathrm{kg} \mathrm{CO}_{2} / \mathrm{y}\right]$

Annual operation $\mathrm{CO}_{2}$ emissions $\left[\mathrm{kg} \mathrm{CO}_{2} / \mathrm{y}\right]$

Demand

Disability-Adjusted Life Year

Electricity demand [MWh/y]

Purchased electricity $[\mathrm{kW}]$

Sold electricity $[\mathrm{kW}]$

Electricity

Equivalent electrical efficiency [\%]

Eco-indicator 99

$\mathrm{CO}_{2}$ emissions associated with electricity $\left[\mathrm{kg} \mathrm{CO}_{2} / \mathrm{kWh}\right]$

$\mathrm{CO}_{2}$ emissions associated with natural gas $\left[\mathrm{kg} \mathrm{CO}_{2} / \mathrm{kWh}\right]$

Consumption of natural gas by cogeneration modules [MWh/y]

Consumption of natural gas [kW]

Amortization and maintenance factor $\left[\mathrm{y}^{-1}\right]$

Environmental amortization factor $\left[\mathrm{y}^{-1}\right]$

Double effect absorption chiller 
FAWH Single effect absorption chiller

GHG Greenhouse gas

HCFCs Hydrochlorofluorocarbons

HFCs Hydrofluorocarbons

FMWR Mechanical chiller

ICVA Vapor-hot water heat exchanger

ICWH Hot water-cooling water heat exchanger

ICWR Cooling tower

IPCC Intergovernmental Panel on Climate Change

LCA Life Cycle Assessment

LCI Life Cycle Inventory

LCIA Life Cycle Inventory Assessment

MGWH Gas engine + hot water recovery system

MJ surplus additional energy that will be needed in the future to extract resources

MILP $\quad$ Mixed linear integer programming

$\mathrm{N}_{2} \mathrm{O} \quad$ Nitrous oxide

NIN(i) Number of pieces of equipment installed for technology $\mathrm{i}$

P Purchase

PAF Potentially Affected Fraction of species

PDF Potentially Disappeared Fraction

$\mathrm{P}_{\text {nom }}(\mathrm{i}) \quad$ Nominal power of the equipment for technology i [MW]

PES Primary Energy Savings

PFCs Perfluorocarbons

$\mathrm{Q}_{\mathrm{cc}} \quad$ Cogenerated useful heat $[\mathrm{MWh} / \mathrm{y}]$

$\mathrm{Q}_{\mathrm{d}} \quad$ Heat demand $[\mathrm{MWh} / \mathrm{y}]$

$\mathrm{R}_{\mathrm{d}} \quad$ Cooling demand $[\mathrm{MWh} / \mathrm{y}]$

S Sale

$\mathrm{SF}_{6} \quad$ Sulphur hexafluoride

$\mathrm{SS}_{\text {fix }} \quad$ Fixed impact of the equipment, in terms of EI-99 Single Score [points/y]

$\mathrm{SS}_{\text {ope }} \quad$ Operation impact, in terms of EI-99 Single Score [points/y]

$\mathrm{SS}_{\text {tot }} \quad$ Total annual impact, in terms of EI-99 Single Score [points/y]

$\mathrm{SS}_{\mathrm{e}} \quad$ EI-99 Single Score for electricity [points/kWh]

$\mathrm{SS}_{\mathrm{g}} \quad$ EI-99 Single Score for natural gas [points/kWh]

SSI(i) EI-99 Single Score for the production of each piece of equipment $\mathrm{i}$ [points] 
Ambient temperature $\left[{ }^{\circ} \mathrm{C}\right]$

TGVA Gas turbine + heat recovery boiler

VA

High temperature steam

$\mathrm{W}_{\mathrm{c}}$

Cogenerated work by cogeneration modules $[\mathrm{MWh} / \mathrm{y}]$

$\mathrm{W}$

Waste

WC

Cold water

WH

Hot water

WR

Cooling water

$\alpha$

Ratio between local electricity $\mathrm{CO}_{2}$ emissions and natural gas $\mathrm{CO}_{2}$ emissions 


\section{REFERENCES}

[1] Guinée JB. Handbook on life cycle assessment: operational guide to the ISO standards. Dordrecht; Boston: Kluwer Academic Publishers, 2002.

[2] Jacobo GJ. LCA as an environmental evaluation tool for construction technology (El ACV como herramienta de evaluación ambiental de la tecnología de la construcción). Jornadas de Investigación, Universidad Nacional del Nordeste, Argentina, 2004 (In Spanish). See also: <arq.unne.edu.ar/publicaciones/comunicaciones/PONENCIAS\%202004/049-Jacobo.pdf> accessed 14/07/2010

[3] IPCC, Summary for Policymakers. In: Climate Change 2007: Mitigation. Contribution of Working Group III to the Fourth Assessment Report of the Intergovernmental Panel on Climate Change [B. Metz, O. R. Davidson, P. R. Bosch, R. Dave, L. A. Meyer (eds)], Cambridge University Press, Cambridge, United Kingdom and New York, NY, USA, 2007.

[4] Council Directive 93/76/EEC, to limit carbon dioxide emissions by improving energy efficiency (SAVE). Official Diary, L237, 22.09.1993, pp. 0028-0030.

[5] COM 2002/91/EC, directive on the energy performance of buildings. Official Journal, L1, 4.1.2003, pp. 65-71.

[6] COM 2004/8/EC, directive on the promotion of cogeneration based on a useful heat demand in the internal energy market. Official Diary of the EU, 21.2.2004, L52, pp. 50-60.

[7] RD 616/2007, on the promotion of CHP (RD 616/2007 sobre fomento de la cogeneración). Official State Bulletin, 12.05.2007, pp. 20605-20609. (In Spanish).

[8] Serra LM, Lozano MA, Ramos J, Ensinas AV, Nebra SA. Polygeneration and efficient use of natural resources. Energy 2009; 34(5):575-586.

[9] Chicco G, Mancarella P. Distributed multi-generation: A comprehensive view. Renewable and Sustainable Energy Reviews 2009; 13(3): 410-417.

[10] Yokoyama R, Hasegawa Y, Ito K. A MILP decomposition approach to large scale optimization in structural design of energy supply buildings. Energy Conversion and Management 2002; 43(6):771-790.

[11] Liu P, Gerogiorgis DI, Pistikopoulos EN. Modeling and optimization of polygeneration energy systems. Catalysis Today 2007; 127(1-4):347-359.

[12] Casisi M, Pinamonti P, Reini M. Optimal lay-out and operation of combined heat \& power (CHP) distributed generation systems. Energy, Volume 34, Issue 12, December 2009, Pages 2175-2183.

[13] Lozano MA, Ramos JC, Carvalho M, Serra LM. Structure optimization of energy supply systems in tertiary sector buildings. Energy and Buildings 2009; 41(10):1063-1075.

[14] Lozano MA, Ramos JC, Serra LM. Cost optimization of the design of CHCP (combined heat, cooling and power) systems under legal constraints. Energy 2010; 35(2): 794-805. 
[15] Klemeš J, Friedler F. Advances in process integration, energy saving and emissions reduction. Applied Thermal Engineering 2010; 30(1):1-5.

[16] Ryan W. Driving absorption chillers using heat recovery. ASHRAE Journal 2004; 46(9):S30-S36.

[17] Teopa E, Picón M, Rodríguez MA. Thermal integration of trigeneration systems, Applied Thermal Engineering 2005; 25(7):973-984.

[18] Sánchez S. Optimal design of trigeneration systems with reciprocating internal combustion engines for the residential-commercial sector (Diseño óptimo de sistemas de trigeneración con motores alternativos de combustión interna para el sector residencial comercial). Mechanical Engineering Department, University of Zaragoza, Spain. 2003 (In Spanish).

[19] RMITC 7575/2007 of the Ministry of Industry, Tourism and Trade, on the supply tariffs of natural gas (RESOLUCIÓN 7575/2007 del Ministerio de Industria, Turismo y Comercio sobre tarifas de suministro de gas natural). BOE 87, pp.15600-15601. 2007 (In Spanish).

[20] RD 1634/2006, on the establishment of electric tariffs from Jan. 1, 2007 (RD 1634/2006, por el que se establece la tarifa eléctrica a partir de 1 de enero de 2007). BOE 312, pp.4665646672. 2006 (In Spanish).

[21] $\mathrm{RD} 661 / 2007$, on the regulation of electricity production in a special regime (RD 661/2007, por el que se regula la actividad de producción de energía eléctrica en régimen especial). BOE 126, pp. 22846-22886. 2007 (In Spanish).

[22] Cardona E, Piacentino A. Cogeneration: a regulatory Framework toward growth. Energy Policy 2005; 33(6):2100-2111.

[23] Rogner H.-H, Zhou D, Bradley R, Crabbé P, Edenhofer O, Hare B, et al. Introduction. In Climate Change 2007: Mitigation. Contribution of Working Group III to the Fourth Assessment Report of the Intergovernmental Panel on Climate Change [B. Metz, O.R. Davidson, P.R. Bosch, R. Dave, L.A. Meyer (eds)], Cambridge University Press, Cambridge, United Kingdom and New York, NY, USA, 2007.

[24] Levine M, Ürge-Vorsatz D, Blok K, Geng L, Harvey D, Lang S, et al. Residential and commercial buildings. In Climate Change 2007: Mitigation. Contribution of Working Group III to the Fourth Assessment Report of the Intergovernmental Panel on Climate Change [B. Metz, O.R. Davidson, P.R. Bosch, R. Dave, L.A. Meyer (eds)], Cambridge University Press, Cambridge, United Kingdom and New York, NY, USA. 2007.

[25] Goedkoop M, Effting S, Collignon M. The Eco-indicator 99. PRé Consultants B.V., Amersfoot, 2000.

[26] Sonnemann G, Castells F, Schuhmacher M. Integrated Life-Cycle and Risk Assessment for Industrial Processes. CRC Press, USA, 2003. 
[27] Lopez AD, Mathers CD, Ezzati M, Murray CJL, Jamison DT. Global burden of disease and risk factors. New York, Oxford University Press, 2006. See also: $<$ www.dcp2.org/pubs/GBD> accessed 14/07/2010

[28] Hauschild, MZ. Assessing Environmental Impacts in a Life-Cycle Perspective. Environmental Science and Technology 2005; 39(4):81A-88A.

[29] SIMAPRO - Life cycle assessment software. PRé Consultants. See also: $<$ www.pre.nl/simapro> accessed 14/07/2010

[30] IDEMAT. Section for Environmental Product Development, Faculty of Industrial Design, Delft University of Technology. The Netherlands, 2001. See also <www.idemat.nl $>$ accessed 14/07/2010

[31] Ecoinvent v2.0 Database. Swiss Centre for Life Cycle Inventories. Dübendorf, Switzerland. 2007.

[32] REE - Red Eléctrica de España (Power network of Spain). The Spanish electricity system in 2007 (El sistema eléctrico español en el 2007). 2007 (In Spanish). See also:

$<$ ree.es/sistema_electrico/pdf/infosis/Inf_Sis_Elec_REE_2007_ElSectorElectrico_v2.pdf $>$ accessed 14/07/2010

[33] Dones R, Bauer C, Bolliger R, Burger B, Faist Emmenegger M, Frischknecht R, Heck T, Jungbluth N, Röder A, Tuchschmid M. Life cycle inventories of energy systems: Results for current systems in Switzerland and other UCTE countries. Ecoinvent report No. 5. Paul Scherrer Institut Villigen, Swiss Centre for Life Cycle Inventories, Dübendorf, Switzerland, 2007.

[34] Frischknecht R, Jungbluth, N. SimaPro Database Manual - The ETH-ESU 96 libraries. ESU services, 2004. See also: <pre.nl/download/manuals/DatabaseManualETH-ESU96.pdf> accessed 14/07/2010

[35] Directive 2005/55/EC. Relating to the measures to be taken against the emission of gaseous and particulate pollutants from compression-ignition engines for use in vehicles. Official Journal of the European Union, October 20, 2005. See also: <eurlex.europa.eu/LexUriServ/LexUriServ.do?uri=OJ:L:2005:275:0001:0163:EN:PDF> accessed 14/07/2010

[36] LINDO Systems. LINGO: The modeling language and optimizer. See also: $<$ Www.lindo.com> accessed 14/07/2010

[37] Carvalho M, Serra LM, Lozano MA. Geographic evaluation of trigeneration systems in the tertiary sector. Effect of climatic and electricity supply conditions. Energy 2010, doi:10.1016/j.energy.2010.02.036.

[38] Meunier F. Co- and tri-generation contribution to climate change control. Applied Thermal Engineering 2002; 22(6): 703-718. 
[39] Chevalier C, Meunier F. Environmental assessment of biogas co- or tri-generation units by life cycle analysis methodology. Applied Thermal Engineering 2005; 25(17-18):30253041 .

[40] Chicco G, Mancarella P. Assessment of the greenhouse gas emissions from cogeneration and trigeneration systems. Part I: Models and indicators. Energy 2008;33(3):410-417.

[41] Mancarella P, Chicco G. Assessment of the greenhouse gas emissions from cogeneration and trigeneration systems. Part II: Analysis techniques and application cases. Energy 2008; 33(3):418-430.

[42] Dorer V, Weber A. Energy and $\mathrm{CO}_{2}$ emissions performance assessment of residential micro-cogeneration systems with dynamic whole-building simulation programs. Energy Conversion and Management 2009; 50 (3):648-657.

[43] Rentizelas A, Tolis A, Tatsiopoulos I. Biomass District Energy Trigeneration Systems: Emissions Reduction and Financial Impact. Water Air Soil Pollution: Focus 2009; 9(1-2):139150.

[44] Genon G, Torchio M, Poggio A, Poggio M. Energy and environmental assessment of small district heating systems: Global and local effects in two case-studies. Energy Conversion and Management 2009; 50 (3):522-529.

[45] Fumo N, Mago P, Chamra L. Emission operational strategy for combined cooling, heating, and power systems. Applied Energy 2009; 86(11):2344-2350.

[46] Compernolle T, Witters N, Passel S, Thewys T. Analyzing a self-managed CHP system for greenhouse cultivation as a profitable way to reduce CO2-emissions. Energy 2010, doi:10.1016/j.energy.2010.02.045.

[47] Wang J, Zhai Z, Jing Y, Zhang C. Optimization design of BCHP system to maximize to save energy and reduce environmental impact. Energy 2010; 35(8):3388-3398.

[48] COM 2007/74/EC, Commission Decision of 21 December 2006 establishing harmonised efficiency reference values for separate production of electricity and heat in application of Directive 2004/8/EC of the European Parliament and of the Council (notified under document number C(2006) 6817). L32, 6.2.2007, pp. 183-188.

[49] REE - Red Eléctrica de España (Power network of Spain). 2010. (In Spanish). See also: $<$ www.ree.es $>$ accessed 28/07/2010

[50] U.S. EPA - United States Environmental Protection Agency. eGRID2007 Version 1.1. 2008. See also: <epa.gov/cleanenergy/documents/egridzips/eGRID2007_Version1-1.zip> accessed 14/07/2010

[51] U.S. EIA - United States Energy Information Administration, Independent Statistics and Analysis. Carbon emission factors - Quadrillion $\left(10^{15}\right)$ BTU, 2006.

[52] U.K. DEFRA - United Kingdom Department for Environment, Food and Rural Affairs, Guidelines to Defra's GHG Conversion Factors, 2008. See also: 
$<$ defra.gov.uk/environment/business/reporting/pdf/ghg-cf-guidelines-annexes2008.pdf $>$ accessed 14/07/2010

[53] JAPAN - The Federation of Electric Power Companies of Japan. Energy and Environment - Japan Electric Power Industry in the World. 2008. See also: <www.fepc.or.jp/english/library/energy_environment/_icsFiles/afieldfile/2008/12/12/Energy _Environment_2007_2008.pdf> accessed 14/07/2010

[54] CANADA - Natural Resources Canada. Guide for computing $\mathrm{CO}_{2}$ emissions related to energy use. 2009. See also: <canmetenergie-canmetenergy.rncannrcan.gc.ca/fichier.php/codectec/En/2001-66/2001-66e.pdf> accessed 14/07/2010 


\section{FIGURE CAPTIONS}

Figure 1: Superstructure of the energy supply system.

Figure 2: Relative contribution of the impact categories to the European damage according to the hierarchist perspective, using the hierarchist weighting set. 
TABLES

Table 1 Selected equipment and matrix of production coefficients.

\begin{tabular}{|c|c|c|c|c|c|c|c|c|c|}
\hline \multirow{2}{*}{ Technology } & \multicolumn{2}{|c|}{ Selected equipment } & \multicolumn{7}{|c|}{ Utility } \\
\cline { 2 - 11 }$i$ & Cost & $\begin{array}{c}\text { Nominal } \\
\text { Power } \\
\text { CI }\left(10^{3} €\right)\end{array}$ & CG & VA & WH & WR & AA & WC & EE \\
\hline TGVA & 1530 & 1.21 & -4.06 & +1.83 & +0.53 & & & & $+\mathbf{1}$ \\
\hline MGWH & 435 & 0.58 & -2.45 & & +0.96 & +0.20 & & & $+\mathbf{1}$ \\
\hline CGVA & 182 & 0.78 & -1.20 & $+\mathbf{1}$ & & & & & \\
\hline CGWH & 30 & 0.57 & -1.08 & & $+\mathbf{1}$ & & & & \\
\hline ICVA & 2.5 & 0.40 & & -1.00 & $+\mathbf{1}$ & & & & \\
\hline ICWH & 6.5 & 0.40 & & & -1.00 & $+\mathbf{1}$ & & & \\
\hline FAVA & 370 & 1.26 & & -0.83 & & +1.83 & & $+\mathbf{1}$ & -0.01 \\
\hline FAWH & 200 & 0.49 & & & -1.50 & +2.50 & & $+\mathbf{1}$ & -0.01 \\
\hline FMWR & 175 & 0.49 & & & & +1.23 & & $+\mathbf{1}$ & -0.23 \\
\hline ICWR & 25 & 1.00 & & & & -1.00 & $+\mathbf{1}$ & & -0.02 \\
\hline
\end{tabular}


Table 2 Inventory for the combustion of natural gas $(1 \mathrm{kWh})$

\begin{tabular}{cccc}
\hline Substance & Compartment & Unit & Quantity \\
\hline Nitrogen oxides & Air & $\mathrm{kg}$ & $6.54 \cdot 10^{-4}$ \\
\hline Sulphur oxides & Air & $\mathrm{kg}$ & $8.53 \cdot 10^{-6}$ \\
\hline Carbon monoxide & Air & $\mathrm{kg}$ & $4.74 \cdot 10^{-6}$ \\
\hline Carbon dioxide & Air & $\mathrm{kg}$ & 0.2410 \\
\hline Gas, natural, $30.3 \mathrm{MJ}$ per kg, in the ground & Raw & $\mathrm{kg}$ & 0.0947 \\
\hline
\end{tabular}


Table 3 Characterization factors for EI-99 (Hierarchist perspective)

\begin{tabular}{ccccc}
\hline & \multicolumn{2}{c}{ Human Health } & $\begin{array}{c}\text { Ecosystem } \\
\text { Quality }\end{array}$ & Resources \\
& $\begin{array}{c}\text { Respiratory } \\
\text { Inorganics } \\
\text { DALY } / \mathrm{kg}\end{array}$ & $\begin{array}{c}\text { Climate } \\
\text { Change } \\
\text { DALY } / \mathrm{kg}\end{array}$ & $\begin{array}{c}\text { Acidification and } \\
\text { Eutrophication } \\
\text { PDF· } \mathrm{m}^{2} \cdot \mathrm{y} / \mathrm{kg}\end{array}$ & $\begin{array}{c}\text { Fossil Fuels } \\
\text { MJ surplus } / \mathrm{kg}\end{array}$ \\
\hline Nitrogen oxides & $8.87 \cdot 10^{-5}$ & - & 5.713 & - \\
\hline Sulphur oxides & $5.46 \cdot 10^{-5}$ & - & 1.041 & - \\
\hline Carbon monoxide & - & $3.22 \cdot 10^{-7}$ & - & - \\
\hline Carbon dioxide & - & $2.10 \cdot 10^{-7}$ & - & 4.55 \\
\hline Gas, natural, in the ground & - & - & - &
\end{tabular}


Table 4 Characterization of inventory for the combustion of natural gas ( $1 \mathrm{kWh})$

\begin{tabular}{|c|c|c|c|c|}
\hline & \multirow{2}{*}{\multicolumn{2}{|c|}{ Human Health }} & \multirow{3}{*}{$\begin{array}{c}\text { Ecosystem Quality } \\
\text { Acidification } \\
\text { and Eutrophication } \\
\left(\mathrm{PDF} \cdot \mathrm{m}^{2} \cdot \mathrm{y}\right)\end{array}$} & \multirow{3}{*}{$\begin{array}{c}\text { Resources } \\
\text { Fossil } \\
\text { Fuels } \\
\text { (MJ surplus) } \\
\end{array}$} \\
\hline & & & & \\
\hline & $\begin{array}{l}\text { Respiratory } \\
\text { Inorganics } \\
\text { (DALY) }\end{array}$ & $\begin{array}{l}\text { Climate } \\
\text { Change } \\
(\mathrm{DALY}) \\
\end{array}$ & & \\
\hline Nitrogen oxides & $5.80 \cdot 10^{-8}$ & & $3.74 \cdot 10^{-3}$ & - \\
\hline Sulphur oxides & $4.66 \cdot 10^{-10}$ & & $8.88 \cdot 10^{-6}$ & - \\
\hline Carbon monoxide & & $1.53 \cdot 10^{-12}$ & - & - \\
\hline Carbon dioxide & & $5.06 \cdot 10^{-8}$ & - & - \\
\hline Gas, natural, in the ground & & - & - & 0.431 \\
\hline Total (A) & $1.09 \cdot 1$ & $\mathrm{ALY}$ & $3.75 \cdot 10^{-3} \mathrm{PDF} \cdot \mathrm{m}^{2} \cdot \mathrm{y}$ & 0.431 MJ surplus \\
\hline
\end{tabular}


Table 5 Damage model (Hierarchist perspective) for the combustion of natural gas ( $1 \mathrm{kWh})$

\begin{tabular}{cccc}
\hline & Human Health & Ecosystem Quality & Resources \\
\hline Normalization factors (B) & $\begin{array}{c}65.1 \\
(1 / \mathrm{DALY})\end{array}$ & $\begin{array}{c}1.95 \cdot 10^{-4} \\
\left(1 / \mathrm{PDF} \cdot \mathrm{m}^{2} \cdot \mathrm{y}\right)\end{array}$ & $\begin{array}{c}1.19 \cdot 10^{-4} \\
(1 / \mathrm{MJ} \text { surplus })\end{array}$ \\
\hline Total (C = A $\cdot \mathbf{B}$ ) & & & \\
\hline $\mathbf{7 . 0 9} \cdot 10^{-6}$ & $\mathbf{7 . 3 0} \cdot 10^{-7}$ & $\mathbf{5 . 1 3 \cdot 1 0 ^ { - 5 }}$ \\
\hline
\end{tabular}


Table 6 Weighting factors $(\mathrm{H} / \mathrm{H})$ and EI-99 points for the combustion of natural gas $(1 \mathrm{kWh})$

\begin{tabular}{cccc}
\hline & Human Health & Ecosystem Quality & Resources \\
\hline Weighting factors (D) & $0.3 \cdot 10^{-3}$ & $0.4 \cdot 10^{-3}$ & $0.3 \cdot 10^{-3}$ \\
\hline $\mathrm{C} \cdot \mathrm{D}$ & & & \\
\hline EI-99 Single Score & $2.13 \cdot 10^{-3}$ & $2.92 \cdot 10^{-4}$ & $1.54 \cdot 10^{-2}$ \\
\hline
\end{tabular}


Table 7 EI-99 Single Score (points/kWh) and $\mathrm{CO}_{2}$ emissions $\left(\mathrm{kg} \mathrm{CO}_{2} / \mathrm{kWh}\right)$ per damage category, for $1 \mathrm{kWh}$ of consumed natural gas.

Eco-Indicator 99 Single Score (points/kWh) $\mathrm{CO}_{2}$ emissions

\begin{tabular}{rccccc}
\hline & Human & Ecosystem & & TOTAL \\
& Health & Quality & Resources & EI-99 SS & $\mathrm{kg} \mathrm{CO} / \mathrm{kWh}$ \\
\hline Natural gas combustion (complete) & $2.13 \cdot 10^{-3}$ & $2.92 \cdot 10^{-4}$ & $1.54 \cdot 10^{-2}$ & $1.78 \cdot 10^{-2}$ & $2.41 \cdot 10^{-1}$ \\
\hline Natural gas, at user & $3.64 \cdot 10^{-4}$ & $1.00 \cdot 10^{-4}$ & $1.95 \cdot 10^{-2}$ & $2.00 \cdot 10^{-2}$ & $3.10 \cdot 10^{-2}$ \\
\hline Natural gas consumed in Spain (1 kWh) & $2.49 \cdot 10^{-3}$ & $3.92 \cdot 10^{-4}$ & $3.49 \cdot 10^{-2}$ & $\mathbf{3 . 7 8} \cdot \mathbf{1 0}^{-2}$ & $\mathbf{2 . 7 2}^{-1}$ \\
\hline
\end{tabular}


Table 8 EI-99 Single Score (points/kWh) and $\mathrm{CO}_{2}$ emissions $\left(\mathrm{kg} \mathrm{CO}_{2} / \mathrm{kWh}\right)$ per damage category, for $1 \mathrm{kWh}$ of electricity produced by different power plants and Spanish mix.

Eco-Indicator 99 Single Score (points/kWh) $\quad \mathrm{CO}_{2}$ emissions

\begin{tabular}{rccccc}
\hline & Human & Ecosystem & & TOTAL \\
& Health & Quality & Resources & EI-99 SS & $\mathrm{kg} \mathrm{CO} / \mathrm{kWh}^{-2}$ \\
\hline Coal $^{1}$ & $2.97 \cdot 10^{-2}$ & $3.66 \cdot 10^{-3}$ & $7.50 \cdot 10^{-3}$ & $4.09 \cdot 10^{-2}$ & 1.02 \\
\hline Natural gas in combined cycle $^{2}$ & $2.58 \cdot 10^{-3}$ & $2.80 \cdot 10^{-4}$ & $3.55 \cdot 10^{-2}$ & $3.84 \cdot 10^{-2}$ & $3.98 \cdot 10^{-1}$ \\
\hline Nuclear $^{3}$ & $7.64 \cdot 10^{-4}$ & $9.45 \cdot 10^{-5}$ & $3.85 \cdot 10^{-4}$ & $1.24 \cdot 10^{-3}$ & $7.10 \cdot 10^{-3}$ \\
\hline Hydraulic $^{4}$ & $1.76 \cdot 10^{-4}$ & $5.61 \cdot 10^{-5}$ & $1.38 \cdot 10^{-4}$ & $3.70 \cdot 10^{-4}$ & $3.60 \cdot 10^{-3}$ \\
\hline Eolic $^{5}$ & $6.42 \cdot 10^{-4}$ & $6.43 \cdot 10^{-4}$ & $1.42 \cdot 10^{-3}$ & $2.71 \cdot 10^{-3}$ & $1.70 \cdot 10^{-2}$ \\
\hline Fuel-gas $^{6}$ & $1.62 \cdot 10^{-2}$ & $4.31 \cdot 10^{-3}$ & $6.49 \cdot 10^{-2}$ & $8.55 \cdot 10^{-2}$ & $6.46 \cdot 10^{-1}$ \\
\hline Others $^{7}$ & $1.37 \cdot 10^{-3}$ & $2.62 \cdot 10^{-4}$ & $1.15 \cdot 10^{-2}$ & $1.31 \cdot 10^{-2}$ & $1.32 \cdot 10^{-1}$ \\
\hline Spanish electricity mix (1 kWh) & $8.83 \cdot 10^{-3}$ & $1.17 \cdot 10^{-3}$ & $1.26 \cdot 10^{-2}$ & $\mathbf{2 . 2 6 \cdot 1 0 ^ { - 2 }}$ & $\mathbf{3 . 8 5}^{-1}$ \\
\hline Spand
\end{tabular}

Spanish electricity mix: 25.8\% Coal, 24.4\% Natural gas -combined cycle-, 19.7\% Nuclear, 9.4\% Hydraulic, 9.4\% Eolic, $0.9 \%$ Fuel-gas, and $10.4 \%$ Others (Biomass, Natural gas -cogeneration-, Minihydraulic) [32].

${ }^{1}$ Coal: average net efficiency of Spanish hard coal power plants $(35.8 \%)$.

${ }^{2}$ Natural gas in combined cycle: refers to the best technology, based on operation data of a German plant built in 2001, with net efficiency of $57.5 \%$.

${ }^{3}$ Nuclear: Swiss nuclear mix (electricity delivered in the period 1995 - 1999) of 55\% Pressure Water Reactor and $45 \%$ Boiling Water Reactor (U enriched 3.8\%).

${ }^{4}$ Hydraulic: Includes shares of electricity produced by of run-of-river and reservoir hydropower plants in Spain. Electricity production shares are determined on annual average and on the level of net production, average efficiency $78 \%$.

Eolic: Technology of a specific $600 \mathrm{~kW}$ wind power plant in Mt. Crosin, Switzerland; the capacity factor is $14 \%$ (efficiency 93\%).

${ }^{6}$ Fuel-gas: estimation for the Spanish specific efficiency of transformation, data were given aggregated for oil and gas use (fuel-gas for peninsular Spain), with an average overall efficiency of $34 \%$.

7 Others: Equal shares of Biomass (efficiency 32\%), Natural gas -cogeneration- (efficiency 44\%), Minihydraulic (efficiency $78 \%)$ 
Table 9 Technologies, main material composition, $\mathrm{CO}_{2}$ emissions, and EI-99 Single Score.

\begin{tabular}{cccc}
\hline Technology & Material composition $(\mathrm{kg})$ & $\mathrm{CO}_{2} \mathrm{I}\left(\mathrm{kg} \mathrm{CO}_{2}\right)$ & $\mathrm{SSI}_{(\mathrm{points})}$ \\
\hline TGVA & $9080 \mathrm{~kg}$ steel, $500 \mathrm{~kg}$ aluminum & 80,500 & 8700 \\
\hline MGWH & $5700 \mathrm{~kg}$ steel & 37,350 & 4030 \\
\hline CGVA & $1000 \mathrm{~kg}$ cast iron, $1850 \mathrm{~kg}$ steel, $50 \mathrm{~kg}$ aluminum & 15,810 & 1420 \\
\hline CGWH & $850 \mathrm{~kg}$ steel, $25 \mathrm{~kg}$ aluminum & 3050 & 205 \\
\hline ICVA & $360 \mathrm{~kg}$ stainless steel & 2350 & 251 \\
\hline ICWH & $760 \mathrm{~kg}$ stainless steel & 5010 & 532 \\
\hline FAVA & $3700 \mathrm{~kg}$ iron alloy, 10,044 kg steel & 98,600 & 11,100 \\
\hline FAWH & $9000 \mathrm{~kg}$ steel & 58,900 & 5890 \\
\hline FMWR & $20 \mathrm{~kg}$ aluminum, $2000 \mathrm{~kg}$ steel, $500 \mathrm{~kg}$ copper, $1000 \mathrm{~kg}$ high-impact PVC & 85,420 & 3130 \\
\hline ICWR & $3500 \mathrm{~kg}$ steel, $1605 \mathrm{~kg}$ high-impact PVC & 23,530 & 2990 \\
\hline
\end{tabular}


Table 10 Results for the Eco-indicator 99 optimal, $\mathrm{CO}_{2}$ optimal, and economic optimal.

\begin{tabular}{|c|c|c|c|c|c|c|}
\hline \multirow[b]{2}{*}{ Composition } & \multicolumn{2}{|r|}{$\mathrm{CO}_{2}$} & \multicolumn{2}{|c|}{ Eco-indicator 99} & \multicolumn{2}{|c|}{ Economic } \\
\hline & Number & Installed Power & Number & Installed Power & Number & $\begin{array}{l}\text { Installed } \\
\text { Power }\end{array}$ \\
\hline TGVA, CGVA & - & 0 & - & 0 & 0 & 0 \\
\hline MGWH & - & 0 & - & 0 & 3 & $1739 \mathrm{~kW}$ \\
\hline CGWH & 6 & $3420 \mathrm{~kW}$ & 6 & $3420 \mathrm{~kW}$ & 3 & $1710 \mathrm{~kW}$ \\
\hline ICWH & 0 & 0 & 0 & 0 & 4 & $1600 \mathrm{~kW}$ \\
\hline ICVA, FAVA & 0 & 0 & 0 & 0 & 0 & 0 \\
\hline FAWH & 0 & 0 & 0 & 0 & 1 & $490 \mathrm{~kW}$ \\
\hline FMWR & 4 & $1960 \mathrm{~kW}$ & 4 & $1960 \mathrm{~kW}$ & 3 & $1470 \mathrm{~kW}$ \\
\hline ICWR & 3 & $3000 \mathrm{~kW}$ & 3 & $3000 \mathrm{~kW}$ & 3 & $3000 \mathrm{~kW}$ \\
\hline $\mathrm{F}_{\mathrm{g}}$ & \multicolumn{2}{|c|}{$8703 \mathrm{MWh} / \mathrm{y}$} & \multicolumn{2}{|c|}{$8703 \mathrm{MWh} / \mathrm{y}$} & \multicolumn{2}{|c|}{$37,324 \mathrm{MWh} / \mathrm{y}$} \\
\hline$E_{p}$ & \multicolumn{2}{|c|}{$3572 \mathrm{MWh} / \mathrm{y}$} & \multicolumn{2}{|c|}{$3572 \mathrm{MWh} / \mathrm{y}$} & \multicolumn{2}{|c|}{$29 \mathrm{MWh} / \mathrm{y}$} \\
\hline $\mathrm{E}_{\mathrm{s}}$ & \multicolumn{2}{|c|}{-} & \multicolumn{2}{|c|}{-} & \multicolumn{2}{|c|}{ 11,389 MWh/y } \\
\hline Cost of equipment & \multicolumn{2}{|c|}{$219,650 € / y$} & \multicolumn{2}{|c|}{$219,650 € / y$} & \multicolumn{2}{|c|}{$510,830 € / y$} \\
\hline Cost of $F_{g}$ & \multicolumn{2}{|c|}{$217,582 € / y$} & \multicolumn{2}{|c|}{$217,582 € / y$} & \multicolumn{2}{|c|}{$933,092 € / y$} \\
\hline Cost of $E_{p}$ & \multicolumn{2}{|c|}{$366,951 € / y$} & \multicolumn{2}{|c|}{$366,951 € / y$} & \multicolumn{2}{|c|}{$3207 € / y$} \\
\hline Profit with $\mathrm{E}_{\mathrm{s}}$ & \multicolumn{2}{|r|}{-} & \multicolumn{2}{|r|}{-} & \multicolumn{2}{|c|}{$-876,960 € / y$} \\
\hline Total cost & \multicolumn{2}{|c|}{$804,184 € / y$} & \multicolumn{2}{|c|}{$804,184 € / y$} & \multicolumn{2}{|c|}{$570,169 € / y$} \\
\hline $\begin{array}{c}\text { Environmental load of } \\
\text { equipment }\end{array}$ & \multicolumn{2}{|c|}{$43,057 \mathrm{~kg} \mathrm{CO}_{2} / \mathrm{y}$} & \multicolumn{2}{|c|}{2272 points/y } & \multicolumn{2}{|c|}{$52,699 \mathrm{~kg} \mathrm{CO}_{2} / \mathrm{y}$} \\
\hline $\mathrm{EM}_{\mathrm{g}} \cdot \mathrm{F}_{\mathrm{g}}$ & \multicolumn{2}{|c|}{$2,367,296 \mathrm{~kg} \mathrm{CO}_{2} / \mathrm{y}$} & \multicolumn{2}{|c|}{328,984 points/y } & \multicolumn{2}{|c|}{$10,152,037 \mathrm{~kg} \mathrm{CO}_{2} / \mathrm{y}$} \\
\hline $\mathrm{EM}_{\mathrm{e}} \cdot \mathrm{E}_{\mathrm{p}}$ & 1,37 & $264 \mathrm{~kg} \mathrm{CO}_{2} / \mathrm{y}$ & & 730 points/y & 11,10 & $\mathrm{~kg} \mathrm{CO}_{2} / \mathrm{y}$ \\
\hline $\mathrm{EM}_{\mathrm{e}} \cdot \mathrm{E}_{\mathrm{s}}$ & & - & & - & 4,384, & $\mathrm{kg} \mathrm{CO}_{2} / \mathrm{y}$ \\
\hline Total environmental load & 3,78 &, $617 \mathrm{~kg} \mathrm{CO}_{2} / \mathrm{y}$ & 411 & 986 points/y & 5,831 , & $5 \mathrm{~kg} \mathrm{CO}_{2} / \mathrm{y}$ \\
\hline
\end{tabular}


Table 11 Configuration and main flows of the system, in function of the origin of electricity ( $\mathrm{CO}_{2}$ optimal).

\begin{tabular}{|c|c|c|c|}
\hline & Coal & Fuel-gas & $\begin{array}{c}\text { Natural gas } \\
\text { (Combined cycle) } \\
\end{array}$ \\
\hline$\alpha$ factor & 3.75 & 2.38 & 1.46 \\
\hline Composition & Number & Number & Number \\
\hline TGVA, CGVA & - & - & - \\
\hline MGWH & 5 & 5 & 3 \\
\hline CGWH & 1 & 1 & 3 \\
\hline ICWH & 3 & 2 & 1 \\
\hline ICVA, FAVA & - & - & - \\
\hline FAWH & 4 & 3 & - \\
\hline FMWH & - & 1 & 4 \\
\hline ICWR & 6 & 5 & 3 \\
\hline$\overline{F_{g}}$ & $42,882 \mathrm{MWh} / \mathrm{y}$ & $29,300 \mathrm{MWh} / \mathrm{y}$ & $17,148 \mathrm{MWh} / \mathrm{y}$ \\
\hline$E_{p}$ & 0 & 0 & $1573 \mathrm{MWh} / \mathrm{y}$ \\
\hline $\mathrm{E}_{\mathrm{s}}$ & $13,969 \mathrm{MWh} / \mathrm{y}$ & $8522 \mathrm{MWh} / \mathrm{y}$ & $3951 \mathrm{MWh} / \mathrm{y}$ \\
\hline $\mathrm{PES}^{1}$ & $9.77 \%$ & $18.15 \%$ & $22.21 \%$ \\
\hline $\mathrm{CO}_{2} \mathrm{I}$ & $58,161 \mathrm{~kg} \mathrm{CO} 2 / y$ & $57,959 \mathrm{~kg} \mathrm{CO} 2 / \mathrm{y}$ & $53,848 \mathrm{~kg} \mathrm{CO}_{2} / \mathrm{y}$ \\
\hline $\mathrm{EM}_{\mathrm{g}} \cdot \mathrm{F}_{\mathrm{g}}$ & $11,663871 \mathrm{~kg} \mathrm{CO}_{2} / \mathrm{y}$ & $7,969,723 \mathrm{~kg} \mathrm{CO} / \mathrm{y}$ & $4,664,244 \mathrm{~kg} \mathrm{CO}_{2} / \mathrm{y}$ \\
\hline $\mathrm{EM}_{\mathrm{e}} \cdot \mathrm{E}_{\mathrm{p}}$ & 0 & 0 & $626,166 \mathrm{~kg} \mathrm{CO}_{2} / \mathrm{y}$ \\
\hline $\mathrm{EM}_{\mathrm{e}} \cdot \mathrm{E}_{\mathrm{s}}$ & $-14,247,966 \mathrm{~kg} \mathrm{CO}_{2} / \mathrm{y}$ & $-5,505,467 \mathrm{~kg} \mathrm{CO}_{2} / \mathrm{y}$ & $-1,572,353 \mathrm{~kg} \mathrm{CO}_{2} / \mathrm{y}$ \\
\hline Total emissions & $-2,525,935 \mathrm{~kg} \mathrm{CO}_{2} / \mathrm{y}$ & $2,522,215 \mathrm{~kg} \mathrm{CO}_{2} / \mathrm{y}$ & $3,771,904 \mathrm{~kg} \mathrm{CO}_{2} / \mathrm{y}$ \\
\hline
\end{tabular}

${ }^{1}$ Primary Energy Savings (PES) in comparison with the separate production of heat and power, calculated in accordance with COM 2004/8/EC [6] and COM 2007/74/EC [48]. 
Table 12 Emissions associated with electricity and natural gas, per country.

\begin{tabular}{|c|c|c|c|}
\hline \multirow[t]{2}{*}{ Country } & \multicolumn{2}{|c|}{$\mathrm{CO}_{2}$ emissions associated with consumption } & \multirow[t]{2}{*}{$\alpha$ factor } \\
\hline & Electricity (Mix) & Natural gas & \\
\hline United States of America (U.S.A.) & $0.603 \mathrm{~kg} \mathrm{CO} 2 / \mathrm{kWh}$ & $0.191 \mathrm{~kg} \mathrm{CO} 2 / \mathrm{kWh}$ & 3.15 \\
\hline United Kingdom (U.K.) $^{2}$ & $0.537 \mathrm{~kg} \mathrm{CO} 2 / \mathrm{kWh}$ & $0.206 \mathrm{~kg} \mathrm{CO} / \mathrm{kWh}$ & 2.61 \\
\hline Japan $^{3}$ & $0.380 \mathrm{~kg} \mathrm{CO} 2 / \mathrm{kWh}$ & $0.248 \mathrm{~kg} \mathrm{CO} 2 / \mathrm{kWh}$ & 1.53 \\
\hline Spain & $0.385 \mathrm{~kg} \mathrm{CO} / \mathrm{kWh}$ & $0.272 \mathrm{~kg} \mathrm{CO} / \mathrm{kWh}$ & 1.42 \\
\hline Canada $^{4}$ & $0.222 \mathrm{~kg} \mathrm{CO} / \mathrm{kWh}$ & $0.179 \mathrm{~kg} \mathrm{CO} 2 / \mathrm{kWh}$ & 1.24 \\
\hline
\end{tabular}

(1) U.S. [50, 51]; (2) U.K. [52]; (3) JAPAN [53]; (4) CANADA [54]. 
Table 13 Configurations of the systems and main flows, per country $\left(\mathrm{CO}_{2}\right.$ optimal).

\begin{tabular}{|c|c|c|c|c|}
\hline & U.S.A. & U.K. & Japan & Canada \\
\hline Composition & Number & Number & Number & Number \\
\hline TGVA, CGVA & - & - & - & - \\
\hline MGWH & 5 & 5 & 4 & - \\
\hline CGWH & 1 & 1 & 2 & 6 \\
\hline ICWH & 3 & 3 & 1 & - \\
\hline ICVA, FAVA & - & - & - & - \\
\hline FAWH & 4 & 4 & - & - \\
\hline FMWH & - & - & 4 & 4 \\
\hline ICWR & 6 & 6 & 3 & 3 \\
\hline$\overline{F_{g}}$ & $42,886 \mathrm{MWh} / \mathrm{y}$ & $42,886 \mathrm{MWh} / \mathrm{y}$ & $17,861 \mathrm{MWh} / \mathrm{y}$ & $8703 \mathrm{MWh} / \mathrm{y}$ \\
\hline$E_{p}$ & 0 & 0 & $1544 \mathrm{MWh} / \mathrm{y}$ & $3572 \mathrm{MWh} / \mathrm{y}$ \\
\hline $\mathrm{E}_{\mathrm{s}}$ & $13,970 \mathrm{MWh} / \mathrm{y}$ & $13,970 \mathrm{MWh} / \mathrm{y}$ & $4412 \mathrm{MWh} / \mathrm{y}$ & 0 \\
\hline $\mathrm{PES}^{1}$ & $9.76 \%$ & $9.76 \%$ & $22.15 \%$ & 0 \\
\hline $\mathrm{CO}_{2} \mathrm{I}$ & $58,161 \mathrm{~kg} \mathrm{CO}_{2} / \mathrm{y}$ & $58,161 \mathrm{~kg} \mathrm{CO}_{2} / \mathrm{y}$ & $57,278 \mathrm{~kg} \mathrm{CO}_{2} / \mathrm{y}$ & $43,057 \mathrm{~kg} \mathrm{CO} / \mathrm{y}$ \\
\hline $\mathrm{EM}_{\mathrm{g}} \cdot \mathrm{F}_{\mathrm{g}}$ & $8,191,253 \mathrm{~kg} \mathrm{CO} / \mathrm{y}$ & $8,834,545 \mathrm{~kg} \mathrm{CO} / \mathrm{y}$ & $4,429,424 \mathrm{~kg} \mathrm{CO} / \mathrm{y}$ & $1,557,889 \mathrm{~kg} \mathrm{CO}_{2} / \mathrm{y}$ \\
\hline $\mathrm{EM}_{\mathrm{e}} \cdot \mathrm{E}_{\mathrm{p}}$ & 0 & 0 & $586,889 \mathrm{~kg} \mathrm{CO} 2 / \mathrm{y}$ & $793,010 \mathrm{~kg} \mathrm{CO}_{2} / \mathrm{y}$ \\
\hline $\mathrm{EM}_{\mathrm{e}} \cdot \mathrm{E}_{\mathrm{s}}$ & $-8,424,087 \mathrm{~kg} \mathrm{CO}_{2} / \mathrm{y}$ & $-7,502,048 \mathrm{~kg} \mathrm{CO}_{2} / \mathrm{y}$ & $-1,676,537 \mathrm{~kg} \mathrm{CO}_{2} / \mathrm{y}$ & 0 \\
\hline Total emissions & $-174,674 \mathrm{~kg} \mathrm{CO}_{2} / \mathrm{y}$ & $1,390,658 \mathrm{~kg} \mathrm{CO} / \mathrm{y}$ & $3,397,053 \mathrm{~kg} \mathrm{CO} / \mathrm{y}$ & $2,393,956 \mathrm{~kg} \mathrm{CO}_{2} / \mathrm{y}$ \\
\hline
\end{tabular}




\section{FIGURES}

Figure 1

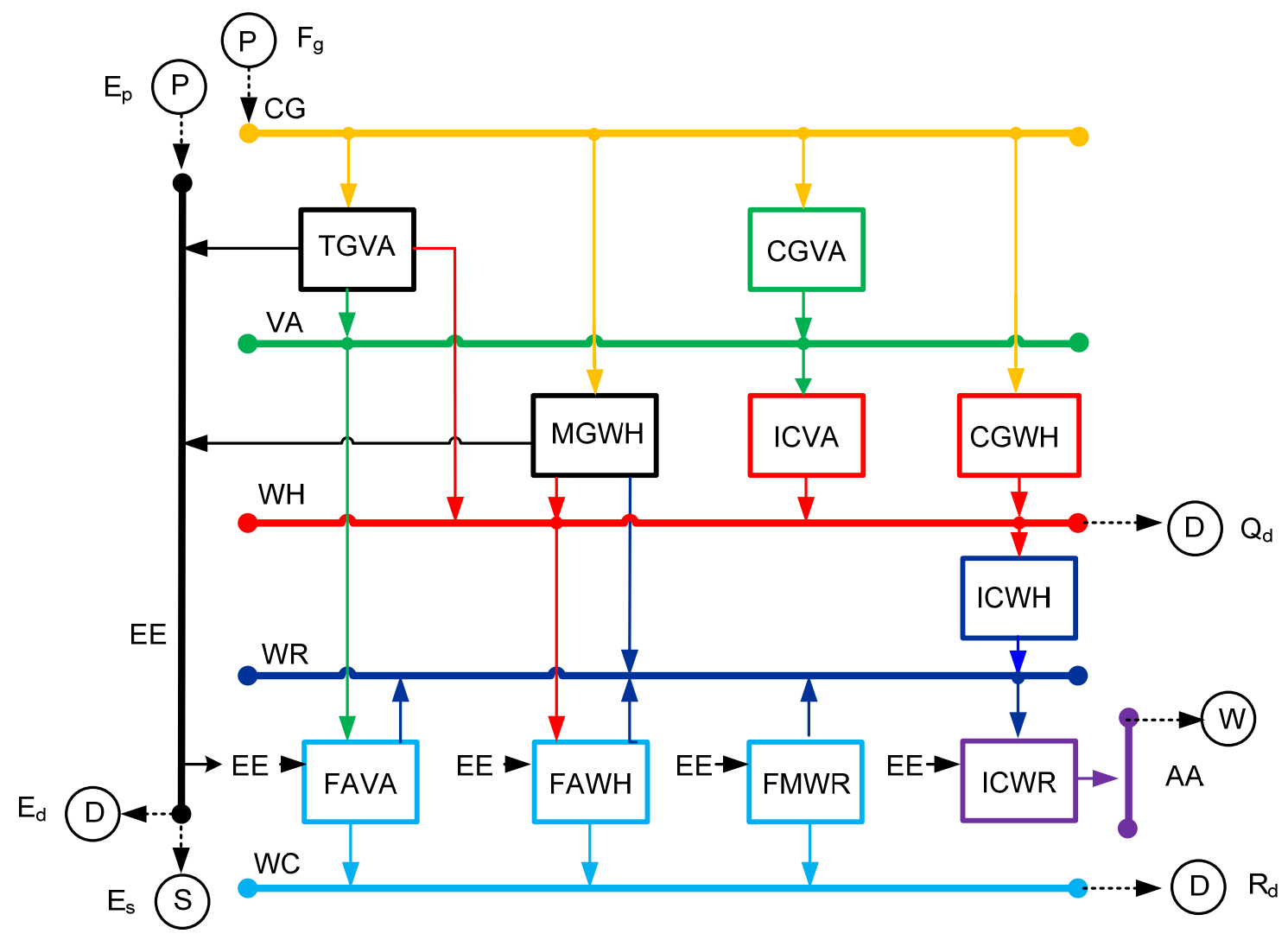


Figure 2

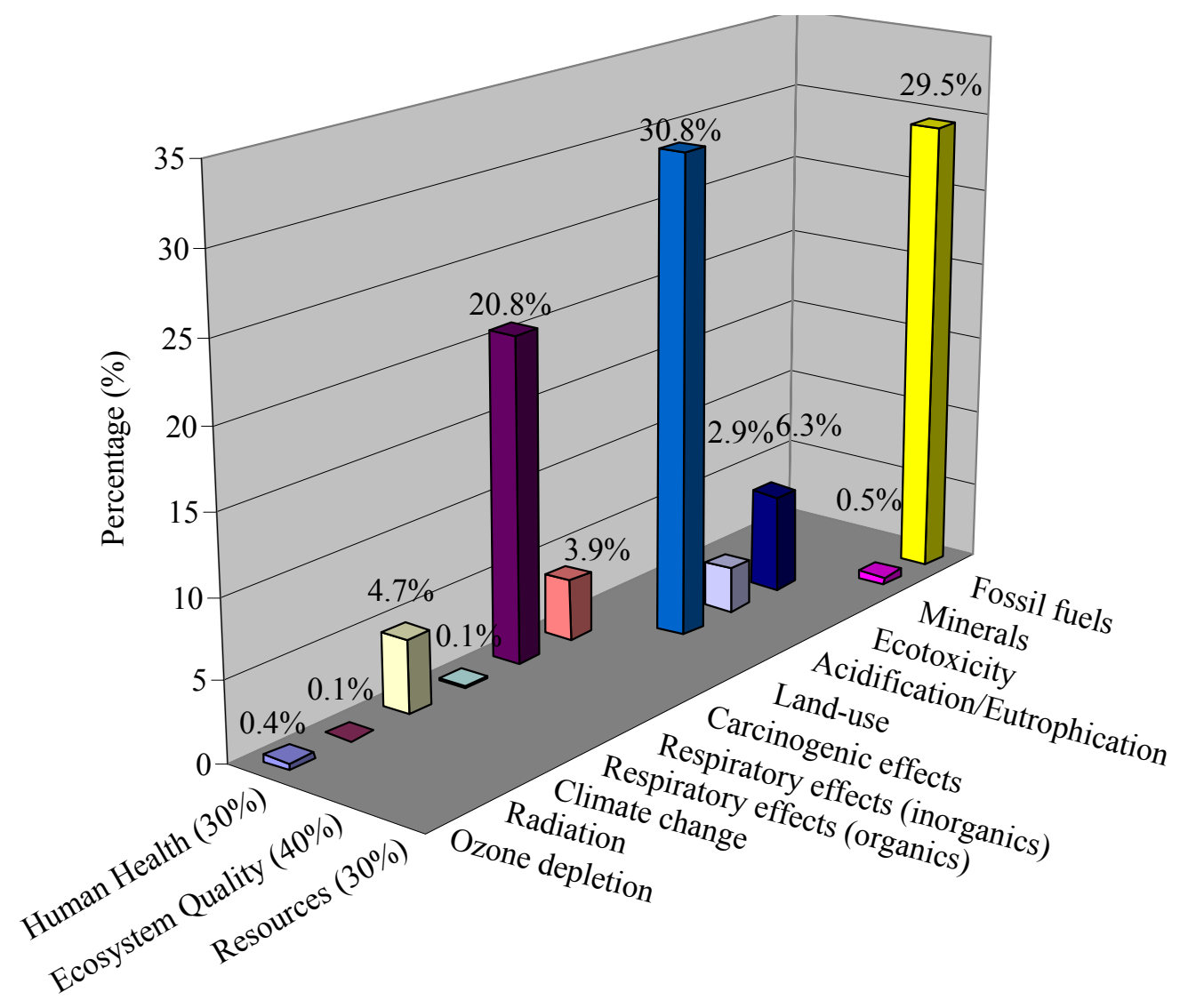

